\title{
Pole semantyczne terminu „książka elektroniczna”
}

\author{
Jarosław Pacek \\ Biblioteka Narodowa
}

\begin{abstract}
Abstrakt
Cel/teza: Celem artykułu jest ustalenie aktualnego znaczenia terminu książka elektroniczna na podstawie jego definicji w źródłach encyklopedycznych i słownikowych.

Koncepcja/metody badań: W badaniach wykorzystano analizę pola semantycznego. Zebrany korpus definicji prezentowanych ( $\mathrm{w}$ j. polskim i angielskim) przeanalizowano w poszukiwaniu kluczowych elementów deskrypcji i wskazano natężenie występowania poszczególnych cech (znaczeń).

Wyniki/wnioski: Artykuł prezentuje wyniki badania, sprawdzającego w jaki sposób książka elektroniczna rozumiana jest w źródłach informacyjnych, oraz która grupa cech formalnych lub abstrakcyjnych, odgrywa istotniejszą rolę w rozumieniu książki.

Oryginalność/wartość poznawcza: Językoznawcza teoria pola semantycznego zakładająca, że każde słowo współwystępuje z innymi w pewnych wyodrębnionych kategoriach znaczeniowych, może znaleźć zastosowanie w badaniach terminologicznych z zakresu informacji naukowej i bibliotekoznawstwa. Zaprezentowane badania przyczynią się do rozwoju terminologii z zakresu tych dyscyplin.
\end{abstract}

\section{Słowa kluczowe}

Bibliologia. Informatologia. Książka elektroniczna. Pole semantyczne. Terminologia.

Otrzymany: 24 maja 2016. Zrecenzowany: 6 lipca 2016. Zaakceptowany: 22 lipca 2016.

\section{Wprowadzenie}

Książka elektroniczna stanowi interesujące zjawisko na tle dotychczasowej historii książki i czytelnictwa. Jednak dokumenty cyfrowe utraciły część cech uznawanych dotychczas przez badaczy za najważniejsze, przede wszystkim kodeksową formę wiążącą zadrukowane, papierowe arkusze. Książki elektroniczne wyróżnia głównie sposób utrwalenia i odczytu, materialnym nośnikiem dla treści staje się przestrzeń nośnika danych cyfrowych. Właściwy nośnik może często znajdować się poza urządzeniem, za pomocą którego wyświetlamy książkową treść, gdy korzystamy z dostępu metodą online. Środowisko cyfrowe sprzyja ponadto zmienności wizualizacji takich książek. Ich forma prezentacji może być różna, zależnie od cyfrowego formatu zapisu i urządzenia, na którym są wyświetlane. Ostateczna postać dokumentów wyświetlanych na ekranie jest również kwestią aktualnie dostępnych rozwiązań technologicznych. Jak się zaś wydaje, zasadniczą cechą książki tradycyjnej jest stabilność i niezmienność. Tymczasem książka elektroniczna może być pewnym konstruktem pojęciowym, którego znaczenie rozciąga się na inne typy elektronicznych dokumentów. Zdaniem Małgorzaty Góralskiej $(1996,37)$ termin ten 
stanowić może również pewien nadrzędny termin dla różnych publikacji cyfrowych, nawet jeśli dzieła te pod względem formy i realizacji typograficznej znacznie odbiegają od swych drukowanych odpowiedników.

Pytanie zasadnicze, które można postawić przy okazji podobnych rozważań brzmi: czy obiekty, które nazywamy książkami elektronicznymi, można zakwalifikować do kategorii książek w ogóle? Sebastian Kotuła (2013, 63, 64). wskazał, że

elektroniczna kopia książki drukowanej, także rękopiśmiennej, charakteryzuje się mniejszym stopniem natężenia cechy książkowatości ${ }^{1}$ niż oryginał, na podstawie którego powstała

oraz

należy wyraźnie podkreślić, iż doświadczenie książki oznacza de facto doświadczenie obcowania z czymś materialnym, tj. okładką, określonym kształtem, teksturą, wagą itp. itd. Są to podstawowe elementy i aspekty, które ulegają zatraceniu, gdy książka zostanie przetransformowana do postaci digitalnej. Ważnym elementem książki jest jej typograficzność wiążąca się z faktem, że dana książka została wydrukowana.

Tabela 1. Pytania o uczestnictwo w kulturze książki w ciągu 12 miesięcy poprzedzających badanie (reprezentatywna ogólnopolska próba 3049 respondentów $\mathrm{w}$ wieku co najmniej 15 lat, procentowe wartości danych)

\begin{tabular}{|c|c|c|c|}
\hline Czy w ciagu ostatnich 12 miesięcy.. & Nie & Tak, raz & $\begin{array}{l}\text { Tak, co najmniej } \\
\text { kilka razy }\end{array}$ \\
\hline ...czytał(-a) Pan(-i) ksiqżkę w formacie e-booka? & 95 & 4 & 2 \\
\hline $\begin{array}{l}\text { słuchał(-a) Pan(-i) jakiegoś audiobooka, czyli } \\
\text { ksiqżki w pliku dźwiękowym, czytanej przez } \\
\text { lektora, nagranej na płytę CD lub inny nośnik? }\end{array}$ & 95 & 4 & 2 \\
\hline $\begin{array}{l}\text {..ściqgnqł(-ęła) Pan(-i) jakqś ksiqżkę z internetu } \\
\text { lub czytał(a) jq on-line? }\end{array}$ & 94 & 4 & 1 \\
\hline ...wypożyczył(-a) Pan(-i) jakqś ksiqżkę z biblioteki? & 84 & 7 & 9 \\
\hline $\begin{array}{l}\text {.czytał(-a) Pan(-i) w prasie lub w internecie jakiś } \\
\text { artykuł, recenzję, wywiad z autorem albo inny wpis } \\
\text { lub opinię o ksiq̨żce? }\end{array}$ & 82 & 12 & 6 \\
\hline $\begin{array}{l}\text {.czytał(-a) Pan(-i) dłuższe teksty w formie } \\
\text { elektronicznej (czyli z ekranu i bez użycia } \\
\text { papieru)? }\end{array}$ & 81 & 9 & 9 \\
\hline ..dostał(-a) Pan(-i) jakqás ksiqżkę w prezencie? & 81 & 15 & 5 \\
\hline ...pożyczył(-a) Pan(-i) komuś jakqś ksiqżkę? & 80 & 13 & 7 \\
\hline $\begin{array}{l}\text { podarował(-a) Pan(-i) komuś ksiqż̇kę w } \\
\text { prezencie? }\end{array}$ & 79 & 16 & 6 \\
\hline ..pożyczył(-a) Pan(-i) od kogoś jakqś ksiqżkę? & 77 & 15 & 8 \\
\hline ...polecił(-a) Pan(-i) komuś jakqś ksiqż́kę? & 76 & 16 & 9 \\
\hline rozmawiał(-a) Pan(-i) z kimś o ksiqżkach? & 68 & 18 & 14 \\
\hline
\end{tabular}

Źródło: (Michalak et al., 2016, 76)

${ }^{1}$ Książkowatość to termin (odpowiednik angielskiego bookness) zaproponowany przez S. Kotułę, na oznaczenie cechy, jaką musi posiadać obiekt, aby można go było uznać za książkę. 
Mamy zatem do wyboru dwie drogi. Można uznać, że termin „książka” powinno się zarezerwować wyłącznie dla drukowanych, tradycyjnych form, jako wcieleń idealnych. Można też przyjąć interpretację „otwartą” i uznać, że cyfrowa zmiana stanowi naturalny krok w ewolucji i jest kolejną ze znanych nam form książki, opowiadam się za tym właśnie, otwartym ujęciem rozumienia książki. Pamiętamy, że kodeksowa postać również wyłoniła się w wyniku procesów rozwoju i udoskonalania. Książki elektroniczne, cyfrowe, multimedialne, czy nawet wykorzystujące możliwości rzeczywistości rozszerzonej (zob. np.Gmiterek, 2015), można traktować właśnie jako kolejną postać książkowego dokumentu utrwalającego myśl ludzką. Należy jednakże przyznać, że właśnie na materialnym aspekcie książki nadal skupiają się definicje naukowe, encyklopedyczne, słownikowe (Pacek, 2015a; 2015b).

Uzupełnieniem powyższych rozważań dotyczących elektronicznej książki mogą być wyniki badania czytelnictwa zaprezentowane przez Instytut Książki i Czytelnictwa Biblioteki Narodowej w opracowaniu Stan czytelnictwa w Polsce w 2015 roku. Okazuje się, że 8\% zbadanych respondentów posiada w swoich kolekcjach oprócz tradycyjnych, papierowych woluminów, również książki elektroniczne lub książki audio. Z badania obejmującego 2015 r. dowiadujemy się, że $6 \%$ respondentów czytało w ciągu minionego roku książkę w formacie elektronicznym (4\% jeden raz, 2\% kilkakrotnie). Identyczny wynik procentowy dało pytanie o słuchanie książek audio, 5\% przyznało, że pobrało jakąś książkę z Internetu lub czytało ją online (4\% jeden raz, 1\% kilkakrotnie) (Michalak et al., 2016). Te dane ilustruje tabela 1.

\section{Cel i metoda badań}

Celem badań prezentowanych w niniejszym artykule było ustalenie, w jaki sposób rozumiany jest termin „książka elektroniczna” ${ }^{2}$ w źródłach o charakterze informacyjnym (słowniki i encyklopedie, polsko- i angielskojęzyczne). Do realizacji tego celu zastosowano metodę analizy pola semantycznego. Teoria pola semantycznego zakłada, że język jest systemem składającym się z elementów - słów, połączonych z sobą siecią relacji semantycznych. W ten sposób tworzą one określone kategorie, inaczej grupy, lub mapy znaczeniowe. Dla potrzeb przeprowadzonego badania przyjęto rozumienie pola semantycznego zgodne z lingwistyczną definicją

jako uporządkowanej grupy wyrazów powiązanych przynależnością do wspólnej kategorii znaczeniowej (Tokarski, 2012, 362).

Podobne do tego ujęcia jest rozumienie zaprezentowane w Słowniku encyklopedycznym informacji, języków i systemów informacyjno-wyszukiwawczych, zgodnie z którym pole semantyczne to

zbiór wyrażeń pozostających względem siebie w określonych relacjach semantycznych (Bojar, oprac. 2002, 197).

2 W zbadanych źródłach, na oznaczenie tego typu książki, używane są terminy: e-book, e-książka, electronic book, elektroniczna książka, książka elektroniczna. W niniejszym artykule stosowany jest jednolicie termin książka elektroniczna. 
Zastosowana w prezentowanym badaniu metoda zbliża się do założeń analizy pola semantycznego Régine Robin. Według tej autorki

tekst nie jest przezroczysty. Szukanie znaczenia tekstu, zdania, wyrazu, oznacza przeanalizowanie wszystkich jego zastosowań i kontekstów, wymaga ciągłej pracy nad tekstem, pozornego rozłożenia ciągu wypowiedzeniowego i porządku wypowiedzi po to, by złożyć je na powrót zgodnie z czytelnością znaczącą (Robin, 1980, 252).

Zgodnie z metodą R. Robin dokonuje się wyboru słów kluczowych z badanych tekstów, a następnie uporządkowuje zebrany materiał w ramach sześciu, wskazanych przez autorkę, kategorii: określenia podmiotu; jego asocjacji, opozycji, ekwiwalentów (synonimów), działań podmiotu, działań wobec podmiotu. Dla celów prezentowanego badania, zdecydowano się na zastosowanie odmiennego zestawu kategorii (zostaną one scharakteryzowane w trzeciej sekcji). Książka postrzegana jest tutaj z perspektywy bibliologii, bibliotekarstwa i informatologii. Współczesne standardy opisu dokumentów wypracowały własne propozycje kategorii porządkujących opis cech książki. Właśnie one zostały wykorzystane do uporządkowania pozyskanego słownictwa. Jak zauważyła Zina Jarmoszuk $(2001,19)$ :

Poszczególne pola, ich zakres i wewnętrzne relacje między wyrażeniami odzwierciedlają rozumienie i widzenie świata charakterystyczne dla danej grupy użytkowników języka.

Należy przywołać także wiadomości o pracach nad językowym obrazem świata podejmowanych w środowisku językoznawców i etnolingwistów lubelskich, działających pod kierunkiem Jerzego Bartmińskiego. W efekcie tych działań publikowany jest Słownik stereotypów $i$ symboli ludowych. Opracowanie ma na celu zbadanie formy i znaczenia języka ludowego oraz rolę stereotypii (topiki, formuł, idiomów) w tekstach folkloru, odtworzenie ludowego obrazu świata (Bartmiński, 1988b, 16). Cechą szczególną tego projektu jest zastosowanie nowatorskiego rodzaju definicji kognitywnej, która polega na zebraniu wszystkich cech ustabilizowanych w językowym obrazie danego przedmiotu (Bartmiński, 1988a, 177). Realizowane jest to poprzez zestawienie fragmentów tekstów źródłowych, zawierających odniesienia do badanych desygnatów rzeczywistości pozajęzykowej. Do uporządkowania zdań definicyjnych zawartych w tak zbudowanej eksplikacji, stosowane są kategorie semantyczne, określane również fasetami (pod wpływem prac Anny Wierzbickiej, a także prac z zakresu informacji naukowej, por. Bartmiński, 2012, 84).

Siatka owych faset pozwala na rekonstrukcję struktury poznawczej haseł, na oddanie ich podmiotowej konceptualizacji, wewnętrznej sieci relacji (UMCS, 2016).

Można więc uznać, że prezentowane w niniejszym artykule badania z zakresu pola semantycznego książki elektronicznej częściowo zbliżają się do metodyki zastosowanej do badań językowego obrazu świata. Głównym punktem styku jest operacja wyboru elementów reprezentatywnych dla desygnatu (fragmentów tekstów i w naszym przypadku słów kluczowych), zestawienie ich ze sobą i zastosowanie uporządkowania wyodrębnionych aspektów (cech, reprezentowanych tutaj przez słowa kluczowe) według pewnych kategorii znaczeniowych.

Badając sposoby definiowania terminów, warto również wyjaśnić relację pomiędzy terminem a pojęciem. Rozważania nad istotą pojęcia są dość częste w literaturze z zakresu informacji naukowej i bibliotekoznawstwa. Jak zauważyła Jadwiga Woźniak-Kasperek $(2015,177)$ : 
Pojęcia są jednostkami mentalnymi, łączącymi się w rodziny, grupy, kategorie. Żeby mogły stać się obiektem jakichkolwiek działań poza umysłem osoby, muszą zostać zeksternalizowane, na przykład w postaci terminu.

W odniesieniu do działalności terminologicznej Jacek Tomaszczyk $(2014,48)$ scharakteryzował dwa sposoby analizy terminologicznej przeprowadzanej na poziomie systemowym, który obejmuje badanie pojęć, tworzenie ich systemu, definiowanie pojęć, przyporządkowywanie im odpowiednich terminów. Analizę terminologiczną można przeprowadzać w drodze od pojęcia do terminu (podejście onomazjologiczne) oraz od terminu do pojęcia (podejście semazjologiczne). Jak wskazuje autor, podejście semazjologiczne stosowane jest najczęściej dla tworzenia słowników ogólnych (filologicznych) i polega na:

(1) Wyborze dziedziny i analizie źródeł z jej zakresu, w celu identyfikacji i selekcji terminów.

(2) Wstępnym określeniu znaczenia terminów; ustaleniu relacji semantycznych między nimi.

(3) Sformułowaniu definicji oraz opcjonalnie, na wyborze ekwiwalentów obcojęzycznych.

Podejście onomazjologiczne również rozpoczyna się od wyboru dziedziny, natomiast kolejnym etapem jest analiza obiektów w celu ustalenia ich właściwości, których podzbiory, odzwierciedlające naturę badanych obiektów (tzw. cechy wystarczające i konieczne) zostaną wykorzystane do opisu pojęć tych obiektów, czyli do procesu konceptualizacji. Kolejne kroki to przyznanie pojęciom nazw roboczych, czyli preterminów, systematyzacja i definiowanie pojęć, następnie przyporządkowanie ostatecznych nazw, czyli terminów, oraz ewentualnie odpowiedników w obcych językach. W tak zarysowanym kontekście metoda badawcza pola semantycznego wydaje się łączyć elementy obydwu dróg analizy terminologicznej. Polega bowiem, zgodnie z ujęciem semazjologicznym, na analizie źródeł i wyborze terminów, ustaleniu relacji semantycznych i na ich podstawie kwalifikowaniu do wspólnych kategorii znaczeniowych. Ta operacja pełni jednocześnie zadania wyznaczone przez podejście onomazjologiczne, ma na celu odzwierciedlić złożoność natury badanego obiektu i ostatecznie prowadzić do konceptualizacji pojęcia. Jacek Tomaszczyk stwierdza, że metoda onomazjologiczna jest w praktyce trudna do realizacji, gdyż wymaga zbudowania schematu struktury badanego pojęcia (można jednak uznać, że pole semantyczne jest właśnie takim schematem) i te etapy konceptualizacyjne muszą poprzedzać dopasowanie właściwych terminów. Tymczasem trudno taki proces zrealizować bez stosowania terminów (przynajmniej w ich postaci roboczej - preterminów), bez których komunikacja, zwłaszcza wykorzystująca język naukowy, jest w zasadzie niemożliwa:

\footnotetext{
Jak w sposób systematyczny wybierać obiekty do analizy, aby zapewnić kompletność i spójność zbioru pojęć i terminów? Wykorzystanie w tym celu literatury przedmiotowej, najważniejszego źródła w pracach leksykograficznych, wydaje się być niezgodne z ideą tego podejścia, ze względu na fakt, iż w tekstach nie występują pojęcia, a reprezentujące je terminy. Nawet najlepszy specjalista dziedzinowy nie zna wszystkich pojęć wchodzących w obszar pojęciowy swojej dziedziny, więc wykorzystanie literatury naukowej i fachowej oraz innych źródeł leksykalnych wydaje się niezbędne. Teoretycznie mogłaby rozwiązać ten problem współpraca wielu specjalistów, ale nie wiadomo, w jaki sposób mieliby oni bez używania terminów komunikować rezydujące w ich umysłach pojęcia. Czy w ogóle możliwe jest identyfikowanie pojęć i opisywanie ich cech bez używania nazw (terminów) pojęć i nazw cech, które również mogą być terminami? (Tomaszczyk, 2014, 49).
} 
Jak również zauważa ten autor, pojęcie jest pierwotne w stosunku do terminu, powstaje wcześniej w umyśle, następnie otrzymuje nazwę. Jednak w rzeczywistości komunikacyjnej niemożliwe jest opisywanie pojęć bez zastosowania odnoszących się do niego terminów. Wydaje się zatem, że można w tym miejscu zaproponować właśnie wykorzystanie techniki badania pola semantycznego do działalności terminologicznej, uwzględniając indeksowanie i grupowanie słownictwa w celu odtworzenia siatki kategorii semantycznych w strukturze pojęcia.

Na potrzeby badania zebrano korpus 23 definicji ${ }^{3}$, których źródła sytuują się w obszarze problemowym bibliologii i informatologii oraz informatyki. Kilka z nich ma charakter ogólnych opracowań encyklopedycznych. Wykorzystane publikacje pochodzą z ostatnich 20 lat. Jest to okres kiedy problematyka związana z książką elektroniczną zajęła już stałe miejsce w dyskursie naukowym. Zebrany materiał został poddany indeksowaniu swobodnemu, w wyniku czego wybrano 57 słów kluczowych, reprezentujących zawartość definicji. Niektóre słowa kluczowe zostały utworzone doraźnie, choć nie pojawiły się bezpośrednio w tekstach definicji, lecz najtrafniej wyrażają treść analizowanego fragmentu ${ }^{4}$. Następnie słowa te zostały pogrupowane w ramach utworzonych kategorii, w których porządek słów wyznaczony został częstotliwością ich występowania w definicjach. W efekcie uzyskano obraz znaczenia książki elektronicznej i wiedzę o tym, jakie jej cechy są uznawane za najistotniejsze. Swoisty obraz, mapa lub pole semantyczne książki elektronicznej rysuje się tu dzięki obserwacji, które z cech są przywoływane w definicjach najczęściej i które są najliczniej reprezentowane za pomocą repertuaru zastosowanych słów kluczowych. Przedstawiane badanie można również zaklasyfikować do obszarów problemowych dziedzin infolingwistyki oraz bibliolingwistyki (zob. Migoń \& Skalska-Zlat, 1995).

\section{Analiza słownictwa}

Wiedzę o znaczeniu terminu książka elektroniczna uzyskano poprzez wykonanie specyficznych operacji na zebranym słownictwie. Zostało ono podzielone na sześć grup, z których pięć odnosi się do fizycznych cech książki elektronicznej oraz związanych z jej obiegiem wydawniczo-księgarskim. Ze względu na wspólną kategorię cech książki wskazywanych przez słowa kluczowe grupy te nazywane są dalej wspólnie „Formalnymi”. Szósta grupa zawiera wyrażenia związane z obszarem, który można nazwać przestrzenią społeczną lub informacyjną książki (Krawczyk, 2009, 16), dlatego określona jest jako „Abstrakcyjna”. W tym miejscu istotne jest także wyjaśnienie, czym charakteryzują się dwa typy informacji statystycznych uzyskanych w badaniu. Pierwszy typ to liczebność, wskazująca jak duża jest grupa słów kluczowych odnoszących się do danej cechy książki elektronicznej, a więc ile słów udało się zakwalifikować do określonej grupy (kategorii). Tego rodzaju statystyka pozwala wnioskować jak szeroki jest repertuar słów (nazw) odnoszących się do danej kategorii cech książki elektronicznej, a więc w jakim stopniu dany obszar został

\footnotetext{
3 W jednym przypadku z jednego źródła zaczerpnięto dwie definicje, stąd 22 a nie 23 pozycje w wykazie źródeł na końcu artykułu.

4 Zgodnie z metodyką indeksowania swobodnego za pomocą języka swobodnych słów kluczowych, „[...] elementarnymi jednostkami leksykalnymi są słowa kluczowe pochodzące z testu indeksowanego dokumentu lub wybrane przez indeksatora z zasobu jego słownika czynnego [...]" (Bojar, oprac. 2002, 111).
} 
rozpoznany i stanowi przedmiot badań wykorzystywany do opisu książki elektronicznej. Wyższa liczebność danej grupy, w porównaniu z innymi, jest efektem szerszego rozpoznania określonej kategorii cech książki elektronicznej i prawdopodobnie wyższej transparentności tych cech i ich reprezentatywności dla danej kategorii. Drugi typ danych to częstotliwość słów, przejawiająca się liczbą przywołań określonych cech książki elektronicznej za pomocą słów kluczowych w definicjach. Indeksowane były pojedyncze wskazania wybranej cechy w danej definicji, a nie każde wystąpienie określonego słowa/znaczenia. W przeciwnym przypadku zostałaby utworzona lista frekwencyjna występowania danych słów, tymczasem celem było ustalenie ile ze zbadanych definicji przywołuje określone cechy książki elektronicznej. Częstotliwość danego słowa oznacza ile definicji (spośród zebranych 23) odniosło się do danej cechy wyrażonej za pomocą słowa kluczowego. Im wyższa częstotliwość tym wyższa „popularność” danej cechy, wyższa jej ranga w rozumieniu terminu książka elektroniczna. Scharakteryzowane dwa typy danych można rozpatrywać oddzielnie oraz komplementarnie. Postrzegane razem tworzą pole semantyczne książki elektronicznej obecne w źródłach encyklopedycznych i słownikowych.

Cechy formalne książki elektronicznej wskazywane w definicjach uszeregowano w ramach pięciu podgrup. Odzwierciedlają one kategorie cech wskazywane również w bibliotekarskich opracowaniach standaryzacyjnych zajmujących się identyfikacją i opisem książek. Wzorowane są na terminologii wykorzystanej w zasadach katalogowania International Standard Bibliographic Description (ISBD), Resource Description and Access (RDA) oraz dokumencie specyfikującym format danych bibliotecznych MARC 21 Format for Bibliographic Data. W ten sposób zebrane słownictwo zakwalifikowano do następujących podgrup: „Budowa nośnika”, „Typ nośnika”, „Typ zawartości”, „Tryb odczytu”. Ponadto na potrzeby właściwej kategoryzacji słownictwa związanego z zagadnieniami obiegu książki na rynku wydawniczo-księgarskim oraz biblioteczno-czytelniczym utworzono podgrupę „Obieg”. Dla aspektów abstrakcyjnych utworzono tylko jedną grupę. Podgrupa „Budowa nośnika” gromadzi słowa związane ze strukturą książki. Słowa kluczowe w podgrupie „Typ nośnika” odzwierciedlają fizyczny format, który przybiera książka; podzbiór „Tryb odczytu” zawiera słowa związane z cechami książki, warunkującymi technikę jej odbioru; „Typ zawartości” wskazuje na formę wyrazu, w której zawartość książki jest komunikowana.

Jak podano wyżej, kategoryzacji poddano 57 słów kluczowych charakteryzujących treść definicji. Ich sumaryczna częstotliwość występowania (dokładniej, częstotliwość powołań na określone cechy książki w definicjach) wyniosła 156 (Tab. 2).

Tabela 2. Porównanie liczebności i częstotliwości słów w podgrupach

\begin{tabular}{|l|c|c|}
\cline { 2 - 3 } \multicolumn{1}{c|}{} & \multicolumn{2}{c|}{ Pole semantyczne książki elektronicznej } \\
\hline Liczba podgrup & Grupa „Formalna” & Grupa „Abstrakcyjna” \\
\hline Łączna liczba słów & 5 & 1 \\
\hline Łączna częstotliwość słów & 56 & 1 \\
\hline
\end{tabular}




\section{Charakterystyka podgrup}

Podgrupa „Tryb odczytu” pojawia się w poniższym zestawieniu na początku, ponieważ pod względem liczebności zajmuje pierwsze miejsce ex aequo z podgrupą „Typ zawartości”. Każda z nich zgromadziła 17 słów. Podgrupa „Tryb odczytu” uzyskała natomiast najwyższą częstotliwość (64). W tej podgrupie znalazły się następujące słowa (liczba w nawiasie oznacza częstotliwość, czyli liczbę definicji, w których słowo się pojawiło): odczyt za pomocą komputera (14), odczyt za pomocą czytnika książek (8), odczyt na urządzeniu przenośnym (7), wyświetlana (6), odczyt za pomocą oprogramowania (5), odczyt za pomocą urządzenia elektronicznego/ cyfrowego (5), odczyt za pomocą telefonu (3), zaznaczanie (3), adnotowanie (2), odczyt za pomocą tabletu (2), podświetlanie (2), wymaga uniwersalnego formatu zapisu (2), czytelna maszynowo (1), na wyświetlaczu podobna do drukowanej (1), odczyt na różnych platformach sprzętowych (1), odczyt za pomocą palmtopa (1), przeszukiwanie (1). Specyfika tej podgrupy polegająca na zgromadzeniu dużej liczby słów, również o wysokiej częstotliwości przywoływania w definicjach, dowodzi, że cechą różnicującą, najbardziej charakterystyczną dla książki elektronicznej, najczęściej wskazywaną w definicjach, jest oryginalny sposób odczytu, polegający na zastosowaniu do tej czynności komputera, lub innych typów urządzeń elektronicznych. „Tryb odczytu” to zdecydowanie najistotniejsza, różnicująca kategoria cech książki tego typu.

Na miejscu drugim znalazła się podgrupa „Typ zawartości”. Jak napisano wyżej, choć zawiera ona również 17 słów kluczowych, jej łączna częstotliwość wyniosła 43. Na tę podgrupę składają się następujące słowa: elektroniczna wersja drukowanej (7), cyfrowa wersja drukowanej (6), tekst (6), dokument elektroniczny (4), efekt konwersji druku do formatu cyfrowego (3), born-digital (2), multimedialna (2), obraz (2), skan (2), tekst cyfrowy (2), animowana (1), atrament elektroniczny (1), dźwięk (1), interaktywna (1), plik tekstowy (1), nie druk (1), tworzenie za pomocą procesora tekstu (1). Identyfikowalny typ zawartości książki elektronicznej pozostaje pod wpływem środowiska cyfrowego, w którym funkcjonuje książka elektroniczna. Jak można zauważyć jest to głównie tekst, ale zapisany elektronicznie/cyfrowo. Zawartość jest wzbogacana również obrazem, dźwiękiem, animacjami. Rozszerza się więc tu oferta wykorzystywanych kodów, czyniąc ten typ książki, w odróżnieniu od książki tradycyjnej, multimedialną.

Podgrupa „Obieg” jest trzecią pod względem liczebności. Składa się na nią 13 słów kluczowych i uzyskała łączną częstotliwość 34. Tworzą ją słowa kluczowe: pobierana (8), internetowa (5), obsługiwana przez biblioteki (3), w obrocie na rynku książki (3), wymaga systemu dostarczania (3), elektroniczna dystrybucja (2), chroniona prawem (2), ładowalna (2), publikacja (2), darmowa (1), dodatek do książki papierowej (1), efektywna w przechowywaniu i transporcie (1), kopiowana (1). W granicach procesów związanych z obiegiem zauważalna jest również wyraźna zmiana w stosunku do obiegu książki tradycyjnej. W przypadku książki elektronicznej podstawową metodą uzyskania do niej dostępu jest pobieranie, ładowanie, dystrybucja w środowisku elektronicznym. Istotne jest podkreślenie, że taka postać książki została zaakceptowana przez instytucje biblioteczne, jest ona przez nie obsługiwana, stanowi także przedmiot ochrony prawnej.

Kolejna podgrupa „Budowa nośnika” zawiera pięć słów kluczowych, zaś jej łączna częstotliwość wynosi sześć. Znalazły się tutaj następujące słowa: wielkość podobna do książki tradycyjnej (2), posiada elementy sterujące (1), mniejsza waga i objętość niż drukowanej (1), mniejsza od książki tradycyjnej (1), lekka (1). Statystyki tej grupy dowodzą, że trudno jest odnosić się 
do budowy i struktury książki elektronicznej, która sama w sobie jest zmienna, tzn. może uzyskiwać różną formę i nośniki. Trudno też w definicji książki elektronicznej podejmować czysto informatyczne zagadnienia struktury plików, aplikacji lub urządzeń elektronicznych.

Ostatnia z tego obszaru podgrupa „Typ nośnika” zawiera już tylko cztery słowa kluczowe, a jej łączna częstotliwość to osiem. Znalazły się tu następujące słowa: czytnik (5), nowa generacja książki (1), nie papier (1), dysk optyczny (1). Może nieco zaskakiwać nieliczna reprezentacja słów tej grupy. Wydawać się mogło, że odniesienia do sposobu utrwalenia treści zawartych w elektronicznej książce, „rodzaj materii” wykorzystanej do stworzenia takiego obiektu, będzie również istotną sferą podkreślaną i różnicującą taki typ książki. Zauważalne jest jednak dość częste utożsamianie książki elektronicznej z urządzeniem czytnikiem cyfrowych treści. Częstotliwość tego słowa zaważyła o wyższej łącznej częstotliwości podgrupy „Typ nośnika” od „Budowy nośnika”, pomimo mniejszej liczby słów.

Oddzielna grupa utworzona została w celu zaszeregowania słów, które można uznać za abstrakcyjne. W istocie ta sfera jest reprezentowana w uzyskanym zbiorze tylko przez jedno słowo kluczowe odnoszące się do „Zawartości książki”. Jest to słowo „dzieło”, które pojawiło się tylko jeden raz w badanych definicjach i uzyskało częstotliwość 1, czyli tylko jedna z definicji wykorzystała je do wyjaśnienia istoty książki. Początkowa interpretacja niskich wyników statystycznych tej grupy podpowiada, że znaczenie abstrakcyjnych sfer zawartości książki jest niewielkie. Wyrażone jest zaledwie jednym słowem, przywołanym w jednej na 23 definicje. Wiemy dzięki temu, że cechy abstrakcyjne nie są najłatwiejszymi do zdefiniowania, opisania i wykorzystania dla eksplikacji książki elektronicznej. Jednakże sytuacja szczególnie słabego odzwierciedlenia cech abstrakcyjnych na mapie semantycznej książki elektronicznej, może mieć jeszcze inne, również interesujące uzasadnienie, które wymaga odpowiedniego dochodzenia. Będzie o tym mowa w kolejnym rozdziale artykułu prezentującym wnioski z przeprowadzonej analizy.

\section{Wnioski}

Przedstawione w artykule wyniki badań pozwalają na wyciągnięcie konkluzji dotyczących jednostkowego typu książki, jaką jest jej elektroniczna forma, ale też w zestawieniu z wcześniejszymi ustaleniami, dowodzą prawdziwości pewnych tez odnoszących się do znaczenia terminu „książka” jako takiego.

Tabela 3. Kategorie formalne pola semantycznego książki elektronicznej (kolejność według częstotliwości)

\begin{tabular}{|l|c|c|}
\cline { 2 - 3 } \multicolumn{1}{c|}{} & \multicolumn{2}{c|}{$\begin{array}{c}\text { Pole semantyczne książki elektronicznej. } \\
\text { Kategorie formalne }\end{array}$} \\
\hline Kategoria & Częstotliwość & Liczebność \\
\hline Tryb odczytu & 64 & 17 \\
\hline Typ zawartości & 43 & 17 \\
\hline Obieg & 34 & 13 \\
\hline Typ nośnika & 8 & 4 \\
\hline Budowa nośnika & 6 & 5 \\
\hline
\end{tabular}


Z zestawienia kategorii cech książki elektronicznej wynika, że najważniejszą cechą różnicującą, wskazywaną przez twórców definicji, jest specyficzny sposób odczytu książki elektronicznej, który wymaga zastosowania urządzenia elektronicznego. To właśnie stanowi jądro znaczenia terminu książka elektroniczna. Inne cechy, szczególnie takie jak abstrakcyjna zawartość, nie stanowią obszaru wyróżniającego w badanym polu semantycznym. Zawartość części abstrakcyjnej nie skupia cech zmiennych, charakterystycznych dla określonego typu książki. Statystyki cech formalnych książki elektronicznej zebrano w tabeli 3.

Mamy zatem do czynienia z dość niezwykłą sytuacją. Z jednej strony obfitość terminów odnoszących się do fizykalnej i utylitarnej funkcjonalności książki i częstotliwość ich przywoływania mogą dowodzić istotnego znaczenia dla wyodrębnienia książki elektronicznej, jako obiektu informacyjnego określonego typu. Z drugiej zaś strony cechy skupione w tym obszarze pola semantycznego są jednocześnie najbardziej zmienne na szerszej mapie znaczenia książki i różnią się w zależności od typu książki, z którą mamy do czynienia. Dla uzyskania pełnej podstawy formułowanych spostrzeżeń należy przywołać wyniki wcześniejszych badań podobnego typu (Pacek, 2015a; 2015b) wykorzystujących teorię pola semantycznego dla ustalenia rozumienia książki jako takiej (w źródłach encyklopedycznych i słownikowych z zakresu bibliologii, informatologii i bibliotekoznawstwa) oraz znaczenia książki w piśmiennictwie o charakterze normalizacyjnym. Wyniki tych badań wykazały zdecydowaną dominację grup formalnych w rozumieniu istoty książki, choć w obydwu przypadkach obszarem pola semantycznego najliczniej reprezentowanym w definicjach i jednocześnie uzyskującym najwyższą częstotliwość była „Budowa nośnika”. W przypadku analizowanej tutaj książki elektronicznej zauważalny jest spadek znaczenia tej podgrupy pola semantycznego na rzecz „Trybu odczytu”. Świadczy to oczywiście o tym, że najistotniejszą różnicą pomiędzy zbadanymi rodzajami książek jest właśnie sposób komunikowania i odbioru ich treści ${ }^{5}$.

Prawdziwa wydaje się zatem teza, że wbrew pozorom, obszar cech fizykalnych nie jest najistotniejszy dla zrozumienia czym jest książka jako taka. Cechy te nie są stałe, nie przenoszą wiedzy pozwalającej na odkrycie tego, co jest elementem wspólnym dla książki bez względu na jej typ. Wobec tego należy zadać pytanie: gdzie jest ukryta cecha/zespół cech stanowiących o idei książki, pozwalających odróżnić książkę jako taką od innych obiektów informacyjnych, bez względu na to, jaką jej „odmianę” będziemy w danej chwili analizowali? Odpowiedzią na to pytanie będzie zarazem kolejna teza: wspólną, najważniejszą cechą książki (w ujęciu naukowym, definicyjnym) jest jej abstrakcyjna zawartość. Jest to zbiór konotacji wywołujących u odbiorcy książki wyobrażenie wiedzy, myśli, komunikatów i pojęć. Grupa słów związanych z abstrakcyjną zawartością, choć stosunkowo nieliczna, uzyskała we wcześniejszych badaniach wysoką łączną częstotliwość. Była często przywoływana w definicjach, co świadczy o wysokim uznaniu dla tego składnika znaczenia książki (zob. Pacek, 2015a). Dla aspektów abstrakcyjnych wspólnym określeniem pojawiającym się w dotychczasowych badaniach pola semantycznego książki jest słowo „dzieło”.

Termin „dzieło” jest wieloznaczny i również nie poddaje się łatwo ujęciom definicyjnym. Bywa różnie rozumiany, w zależności od kręgu kulturowego, obszaru nauki czy kultury,

\footnotetext{
${ }^{5}$ Jednocześnie warto przywołać tutaj obserwację, zgodnie z którą w ogólnych definicjach książki, w bardzo niewielkim stopniu nastąpiła recepcja książki elektronicznej (w 24 definicjach encyklopedycznych i słownikowych ten typ przywołano zaledwie czterokrotnie, zaś w siedmiu definicjach obecnych w piśmiennictwie normalizacyjnym zaledwie jednokrotnie).
} 
w którym jest stosowany. Dokument porządkujący jednostki i relacje uniwersum bibliograficznego - Functional Requirements for Bibliographic Records (FRBR) wprowadza szereg nowych dla bibliotekarstwa jednostek opisu i umieszcza dzieło (ang. work) jako jedną z jednostek naczelnych, lecz przyznaje jej dość niejednoznaczne rozumienie, zgodnie z którym nie istnieje żaden materialny obiekt, który stanowiłby dzieło. Rozpoznawane i postrzegane jest jedynie poprzez swe indywidualne realizacje (czyli formę intelektualną lub artystyczną jaką przyjmuje dzieło za każdym razem kiedy jest wykonywane). Z kolei standard katalogowania RDA definiuje dzieło jako odrębny utwór intelektualny lub artystyczny (tzn. o intelektualnej lub artystycznej zawartości). W normie terminologicznej PN-ISO 5127:2005 Informacja i dokumentacja - Terminologia zamieszczono również dość enigmatyczną definicję dzieła:

Zawartość dokumentu będąca wynikiem działalności twórczej, dzięki której podlega on ochronie copyrightu lub tytułu własności przemysłowej ze względu na indywidualny charakter lub nowość (PN-ISO, 2005, 150).

Pozornie nieco bardziej precyzyjna jest definicja zamieszczona w Nowym słowniku języka polskiego, w którym dzieło jest rozumiane jako

utwór literacki, naukowy, muzyczny, artystyczny, zwykle dużej wartości (Sobol, red. 2002, 172).

Jednak podobnie jak w przypadku zawartości, aby zrozumieć dzieło trzeba dookreślić rozumienie utworu. Uwidacznia się zatem trudność definiowania zjawisk abstrakcyjnych, choć ich znaczenie dla zrozumienia także materialnych obiektów środowiska informacyjnego i kulturowego jest bardzo istotne. Ten fakt stanowi barierę w badaniu fenomenu książki. Analizy pozwalają dostrzec, że to właśnie sfera abstrakcyjna ma prawdopodobnie najistotniejsze znaczenie w materiale definicyjnym dla rozumienia istoty książki jako takiej. Ta sfera znaczenia książki jest trudna do badań, a przez to pozostaje słabo rozpoznana.

\section{Bibliografia}

Bartmiński, J. (1988a). Definicja kognitywna jako narzędzie opisu konotacji słowa. W: J. Bartmiński (red.) Konotacja. Lublin: Wydaw. UMCS, 169-183.

Bartmiński, J. (1988b). Słownik ludowych stereotypów językowych. Założenia ogólne. Etnolingwistyka 1, 11-34.

Bartmiński, J. (2012). Punkt widzenia, perspektywa, jezzykowy obraz świata. Lublin: Wydaw. UMCS, 76-88.

Bojar, B. oprac. (2002). Stownik encyklopedyczny informacji, języków i systemów informacyjno-wyszukiwawczych. Warszawa: Wydaw. SBP.

Gmiterek, G. (2015). Rzeczywistość rozszerzona a książka i prasa. W: G. Gmiterek, M. Ochmański, M. Roszkowski (red.) LaTeI. Z badań nad wykorzystaniem technologii informacyjnych w bibliologii i informatologii. Warszawa: Wydaw. SBP, 41-66.

Góralska, M. (1996). Elektroniczne książki. Zagadnienia Informacji Naukowej, 2, 33-40.

Jarmoszuk, Z. (2001). Pole semantyczne terminu kultura w definicjach kultury. Zagadnienia Informacji Naukowej, 1, 17-34.

Kotuła, S. (2013). Komunikacja bibliologiczna wobec World Wide Web. Lublin: Wydaw. UMCS, 2013.

Krawczyk, A. (2009). Przestrzeń jako kategoria poznawcza przy wyjaśnianiu funkcjonowania książki. W: J. Konieczna, S. Kurek-Kokocińska, H. Tadeusiewicz (red.) Przestrzeń informacyjna książki. Łódź: Wydaw. Biblioteka, 15-26. 
Michalak, D.; Koryś, I.; Kopeć, J. (2016). Stan czytelnictwa w Polsce w 2015 roku [online]. Biblioteka Narodowa, [18.04.2016], http://bn.org.pl/download/document/1459845698.pdf

Migoń, K.; Skalska-Zlat, M. (1995). Bibliolinguistics and bibliometrics - connections and interdependence: theoretical and quantitative analysis. In: M.E.D. Koenig, A. Bookstein (eds.) Fifth International Conference of the International Society for Scientometrics and Informetrics: Proceedings - 1995: June 7-10 1995. Medford: Learned Information, 331-347.

Pacek, J. (2015a). Pole semantyczne książki. Przegląd Biblioteczny, 4, 546-562.

Pacek, J. (2015b). Pole semantyczne książki w tekstach normalizacyjnych i prawnych. Praktyka i Teoria Informacji Naukowej i Technicznej 2, [w druku].

PN-ISO (2005). PN-ISO 5127. Informacja i dokumentacja. Terminologia. Warszawa: PKN.

Robin, R. (1980). Badanie pól semantycznych. Doświadczenia Ośrodka Leksykologii Politycznej w Saint-Cloud. W: M. Głowiński (red.) Język i społeczeństwo. Warszawa: Czytelnik, 205-282.

Sobol E. red. (2002). Nowy stownik języka polskiego. Warszawa: Wydaw. Naukowe PWN.

Tokarski, R. (2012). Słownictwo jako interpretacja świata. W: J. Bartmiński (red.) Wspótczesny język polski. Lublin: Wydaw. UMCS.

Tomaszczyk, J. (2014). Model systemu informacji terminologicznej. Katowice: Wydaw. UŚ.

UMCS (2016). Stownik stereotypów i symboli ludowych [online]. Uniwersytet Marii Curie-Skłodowskiej, [18.04.2016], http://www.umcs.pl/pl/slownik-stereotypow-i-symboli-ludowych,5561.htm\#page-2

Woźniak-Kasperek, J. (2015). Terminologia jako mapa świata. W: G. Gmiterek, M. Ochmański, M. Roszkowski (red.) LaTeI. Z badań nad wykorzystaniem technologii informacyjnych w bibliologii i informatologii. Warszawa: Wydaw. SBP, 174-185.

\section{Wykaz źródeł definicji}

Adamczewski, P. (2005). Stownik informatyczny. Warszawa: Helion.

ALA (2016). Instruction for Diverse Populations Multilingual Glossary. Definitions [online]. ALA American Library Association [29.03.2016], http://www.ala.org/acrl/sites/ala.org.acrl/files/content/ aboutacrl/directoryofleadership/sections/is/iswebsite/projpubs/idpdefinitions.pdf

Bangia, R. (2010). Dictionary of Information Technology. Second Edition. New Delhi: Laxami Publications, Ltd.

Cooper, M. ed. (2005). Illustrated Dictionary of Library and Information Science. New Delhi: Lotus Press.

Czapnik, G.; Gruszka Z. oprac. (2011). Podręczny słownik bibliotekarza. Warszawa: Stowarzyszenie Bibliotekarzy polskich, Uniwersytet Łódzki.

Drake, M. red. (2003). Encyclopedia of Library and Information Science. Second Edition. Vol. 2. New York, Basel: Mercel Dekker, Inc., 803-1590.

Encyclopaedia Britannica (2016). Electronic book [online]. Encyclopaedia Britannica [29.03.2016], http://www.britannica.com/technology/e-book

Henderson, H. (2009). Encyclopedia of Computer Science and Technology. New York: Facts On File.

Kubiak, M. J. red. (1999). Słownik technologii informacyjnej. Warszawa: Mikom.

Levine-Clark, M.; Carter, T. M. eds. (2013). ALA Glossary of Library and Information Science. Fourth Edition. Chicago: American Library Assotiation.

Oxford Dictionaries (2016). E-book [online]. Oxford Dictionaries. Language matters [29.03.2016], http://www.oxforddictionaries.com/definition/english/e-book

Oxford Dictionaries (2016). E-book [online]. Oxfrod Advanced Learner's Dictionary [29.03.2016], http://www.oxforddictionaries.com/definition/learner/e-book

PCMag (2016). E-book [online]. PC Magazine. Technology Product Reviews, News, Prices. Encyclopedia [29.03.2016], http://www.pcmag.com/encyclopedia/term/42214/e-book

Prytherch, R. J. ed. (2012). Harrod's Librarians' Glossary and Reference Book: A Directory of Over 10,200 Terms, Organizations, Projects and Acronyms in the Areas of Information Management, Library Science, Publishing and Archive Management. Tenth Edition, Revised. Burlington: Ashgate Publishing, Ltd. 
PWN (2016). E-book [online]. Słownik języka polskiego PWN [29.03.2016], http://sjp.pwn.pl Quigley, M. ed. (2008). Encyclopedia of Information Ethics and Security. New York: Information Science Reference, cop.

Reitz, J. M. (2016). ODLIS Online Dictionary for Library and Information Science [online]. [29.03.2016], http://www.abc-clio.com/ODLIS/odlis_A.aspx

Suraj V. K. ed. (2005). Encyclopaedic dictionary of library and information science. Vol. 1. Delhi: Isha Books.

Szaniawski, J. red. (1997). Duży stownik informatyczny. Warszawa: ArsKom.

Tomei, L. A. ed. (2008). Encyclopedia of information technology curriculum integration. Hershey, New York: IGI Global.

Wikipedia, English (2016). E-book [online]. Wikipedia. The Free Encyclopedia [29.03.2016], https:// en.wikipedia.org/wiki/E-book

Wikipedia, polska (2016). E-book [online]. Wikipedia. Wolna encyclopedia [29.03.2016], https:// pl.wikipedia.org/wiki/E-book

\title{
Semantic Field of the Term "electronic book"
}

\begin{abstract}
Purpose/Thesis: The purpose of this paper is to study the current meaning of the term "electronic book" based on selected contemporary encyclopaedias and dictionaries.

Approach/Research methods: The study is conducted with semantic field analysis. Definitions were collected from encyclopaedias and dictionaries (in Polish and English) and then studied in search for key elements of descriptions and frequency of particular feature occurrence.

Results and conclusions: The paper presents the results of the analysis of collected definitions and aims to investigate the meaning of the term "electronic book" based on two groups of extracted features - formal and abstract ones.

Originality/Value: The results of the research may be used in terminology studies in the field of Library and Information Science. The research will contribute to the development of terminology in the field of information science and book studies.
\end{abstract}

\section{Keywords}

Book studies. Information science. Electronic books. Semantic field. Terminology.

Dr JAROSŁAW PACEK jest kierownikiem Instytutu Bibliograficznego Biblioteki Narodowej. Publikuje artykuty naukowe $z$ zakresu problemów bibliografii w środowisku cyfrowo-sieciowym, wptywu Internetu na organizację działalności informacyjnej, zmian nośników informacji, terminologii nauki o informacji. Najważniejsze publikacje: Bibliografia w zmieniajacym się środowisku informacyjnym, Warszawa, 2010; Bibliografia w XXI wieku. W: Bibliologia i informatologia, Warszawa 2011, s. 267-279; Pole semantyczne książki. Przeglad Biblioteczny 2015, nr 4, s. 546-562. Jest twórca i redaktorem serwisów sieciowych zwiazanych $z$ działalnościa informacyjna (m.in. Sternik. Stownik terminologiczny z zakresu bibliografii $i$ katalogowania - http://sternik.bn.org.pl/). Jest członkiem Rady Naukowej Biblioteki Narodowej. Należy do Polskiego Towarzystwa Informacji Naukowej oraz do International Society for Knowledge Organization.
Kontakt $z$ autorem:
j.pacek@bn.org.pl
Instytut Bibliograficzny
Biblioteka Narodowa
al. Niepodlegtości 213
02-086 Warszawa 